Journal of Telenursing (JOTING)

Volume 1, Nomor 1, Juni 2019

e-ISSN : 2684-8988

p-ISSN : 2684-8996

DOI: https://doi.org/10.31539/joting.v1i1.494

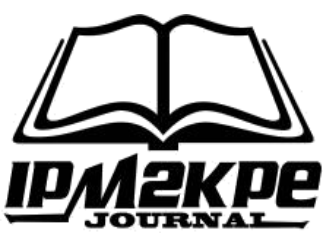

\title{
PENGARUH VIDEO INTERAKTIF DAN MEDIA GAMBAR TERHADAP KEMAMPUAN MERAWAT DIRI PADA ANAK TUNAGRAHITA
}

\author{
Indah Rosmaya ${ }^{1}$, Suhendar Sulaeman ${ }^{2}$, Nyimas Heny Purwati ${ }^{3}$ \\ Universitas Sultan Ageng Tirtayasa ${ }^{1}$ \\ Universitas Muhammadiyah Jakarta ${ }^{2,3}$ \\ ixosman2927@gmail.com ${ }^{1}$
}

\begin{abstract}
ABSTRAK
Penelitian ini bertujuan untuk mengetahui efektivitas video interaktif dan media gambar terhadap kemampuan merawat diri pada anak tunagrahita di SKH Negeri 01 Serang Banten. Penelitian ini merupakan quasy experimental dengan desain non equivalent without control group. Hasil penelitian menunjukkan ada perbedaan rata-rata kemampuan merawat diri anak tunagrahita sebelum dan sesudah diberikan intervensi video interaktif ( $\mathrm{p}$ value $=0,015, \Delta=6,67$ ), ada perbedaan rata-rata kemampuan merawat diri anak tunagrahita sebelum dan sesudah diberikan intervensi media gambar ( $\mathrm{p}$ value $=0,006, \Delta=3,23$ ), dan ada perbedaan rata-rata kemampuan merawat diri anak tunagrahita sebelum dan sesudah diberikan intervensi video interaktif dan media gambar ( $\mathrm{p}$ value $=0,003, \Delta=1,45)$. Simpulan, penggunaan intervensi video interaktif lebih efektif sebagai media pembelajaran dalam meningkatkan kemampuan merawat diri pada anak tuna grahita sedang, namun harus didukung oleh kelengkapan sarana dan prasana.
\end{abstract}

Kata Kunci: Anak Tunagrahita, Perawatan Diri, Media Gambar, Video Interaktif

\section{ABSTRACT}

This study aims to determine the effectiveness of interactive video and image media on the ability to care for mentally retarded children at SKH Negeri 01 Serang Banten. This research is a quasy experimental design with a non equivalent without control group. The results showed that there was a difference in the average ability to care for mentally retarded children before and after being given interactive video intervention ( $p$ value $=0.015, \Delta=6.67$ ), there was a difference in the average ability to care for mentally retarded children before and after being given the intervention of media images. ( $p$ value $=0.006, \Delta=3.23$ ), and there is a difference in the average ability to care for mentally retarded children before and after being given interactive video and image media interventions ( $p$ value $=0.003, \Delta=1.45$ ). In conclusion, the use of interactive video interventions is more effective as a learning medium in improving the self-care ability of children with moderate mental retardation, but it must be supported by complete facilities and infrastructure.

Keywords: Children with mental retardation, Self-Care, Image Media, Interactive Video 


\section{PENDAHULUAN}

Tunagrahita merupakan kondisi yang kompleks, ditujukan oleh fungsi intelektual rendah yaitu dibawah rata-rata, mengalami hambatan dalam perilaku adaptif dan berlangsung pada masa perkembangannya (Hermawan, 2013). Anak tunagrahita mengalami keterbatasan dalam melakukan kegiatan sehari-hari salah satunya adalah merawat diri (Yayasan Pendidikan Dwituna Rawinala, 2017).

Berdasarkan Sensus Nasional (2012) anak tunagrahita menempati jumlah paling besar yaiu 66.610 dibanding jumlah anak dengan kecacatan lainnya. Dari jumlah tersebut, diperkirakan 57\% merupakan anak tunagrahita ringan dan tunagrahita sedang (Kemenkes RI, 2012). Anak tunagrahita sedang yang memiliki IQ 50-70 dinilai mampu dididik untuk melakukan sosialisasi dan bergaul, namun berbeda dengan anak tunagrahita sedang dengan IQ 35-49, (Yayasan Pendidikan Dwituna, 2008).

Anak tunagrahita perlu perhatian dan pendidikan khusus untuk membantu perkembangan intelektual dan kemandiriannya (Somantri, 2007). Tujuan utama dari teori Dorothea E Orem adalah untuk membuat individu atau keluarga dapat melakukan aktivitas sehari-hari dan memenuhi kebutuhannya secara mandiri (Alligood, 2014). Anak tunagrahita sedang, memiliki keterbatasan dalam merawat diri sehingga dibutuhkan peran perawat dalam membantu meningkatkan kemandirian dan kemampuan dalam melakukan perawatan diri. Anak tunagrahita sedang memerlukan waktu lebih lama untuk belajar merawat diri (Yayasan Pendidikan Dwituna, 2008).

Pembelajaran tentang bina diri pada anak tunagrahita umumnya masih di sampaikan melalui metoda ceramah sehingga beberapa informasi tentang perawatan diri tidak sampai kepada anak dan anak cenderung bosan untuk mengikuti pembelajaran terkait bina diri tersebut. Sehingga diperlukan metoda pembelajaran lain yang dapat digunakan untuk meningkatkan kemandirian dalam perawatan diri pada anak tunagrahita adalah dengan pemberian video interaktif dan media gambar.

Media video interaktif merupakan sebuah media pembelajaran yang berisi media atau berupa cerita yang bergerak disertai dengan adanya suara. Media pembelajaran tersebut mengandung banyak pengetahuan dan keterampilan yang secara sederhana dan menarik sehingga anak tunagrahita tidak bosan dengan pembelajaran bina diri (Cahyo, 2011). Hal ini sesuai dengan penelitian yang dilakukan oleh Fajarwati \& Sujarwanto (2015) dimana didapatkan hasil bahwa ada pengaruh yang signifikan dimana penggunaan media video interaktif bermanfaat dalam penigkatan kemampuan membaca permulaan pada anak dengan tunagrahita ringan sedang di SLB Gedangan Harmoni Sidoarjo.

Media gambar cukup banyak diterapkan untuk peningkatan kemampuan anak tunagrahita seperti mengenalkan anggota keluarga, meningkatkan kemampuan untuk memahami angka-angka, serta meningkatkan kemampuan membaca pada anak tunagrahita. Penelitian yang dilakukan oleh Ayu (2017) didapatkan hasil bahwa ada pengaruh media huruf bergambar terhadap kemampuan menulis permulaan pada siswa tunagrahita ringan.

Berdasarkan fenomena tersebut peneliti tertarik untuk melakukan penelitian ini. Tujuan dari penggunaan media gambar adalah untuk menarik perhatian anak, memperjelas penyampaian pesan serta agar anak tunagrahita tidak memiliki rasa bosan saat proses belajar. Hal lain juga dikatakan oleh 1 orang tua bahwa anaknya belum mandiri dalam melakukan perawatan diri yaitu menggosok gigi sehingga selalu dibantu dan 1 orang tua lagi mengatakan bahwa anaknya masih bergantung kepada orang tua, misalnya jika anak mampu mandi sendiri tapi untuk menyisir rambut masih dibantudan 
1 orang tua lagi mengatakan bahwa anaknya selalu di suruh bila mandi dan kadangkadang dibantu untuk mandi dengan benar.Anak dengan tunagrahita sedang tidak dapat memenuhi kebutuhan merawat diri nya secara cepat tapi mampu untuk dilatih sehingga diperlukan metoda pembelajaran lain yang efektif terkait pembelajaran bina diri sehinga anak akan selalu ingat dan tidak bosan dengan pembelajaran yang disampaikan.

\section{METODE PENELITIAN}

Penelitian ini merupakan penelitian quasy experimental dengan rancangan penelitian non equivalent without control group (non randomized without control group pretest-posttest). Total sampel dalam penelitian ini adalah 27 anak tunagrahita sedang yang dibagi kedalam 9 anak pada kelompok intervensi video interaktif, 9 anak pada kelompok media gambar dan 9 anak pada kelompok video interaktif dan media gambar.

Adapun kriteria inklusinya adalah anak tunagrahita sedang, orang tua bersedia anak menjadi responden, tidak memiliki kelainan kongenital atau penyakit lain. Alat pengumpulan data menggunakan lembar kuesioner kemampuan merawat diri 10 item pertanyaan dengan rentang skor 0-40. Hasil uji validitas didapatkan nilai cronbach's alpha 0,947 .

Kelompok video interaktif dan media gambar, intervensi diberikan selama 30 menit dan kelompok video interaktif dan media gambar diberikan 45 menit. Setelah itu dilakukan kembali pengukuran tingkat kemampuan anak. Pengolahan data menggunakan uji yang digunakan adalah paired t test karena data berdistribusi normal.

\section{HASIL PENELITIAN Karakteristik responden}

Tabel 1

Distribusi Frekuensi Responden Berdasarkan Usia Anak, Jenis Kelamin, Agama, Pendidikan Orang Tua, Pekerjaan Orang Tua, Hubungan dengan Anak dan Waktu Merawat Anak (n=27)

\begin{tabular}{lcccccc}
\hline \multicolumn{1}{c}{ Variabel } & \multicolumn{3}{c}{ Frekuensi } & \multicolumn{3}{c}{ Persentase (\%) } \\
\cline { 2 - 7 } & I & II & III & I & II & III \\
\hline 1. Usia & 3 & 2 & 6 & 33,3 & 22,2 & 66,7 \\
a. 10 tahun & 2 & 0 & 1 & 22,2 & 0 & 11,1 \\
b. 11 tahun & 1 & 2 & 0 & 11,1 & 22,2 & 0 \\
c. 12 tahun & 0 & 3 & 1 & 0 & 33,3 & 11,1 \\
d. 13 tahun & 3 & 1 & 1 & 33,3 & 11,1 & 11,1 \\
e. 14 tahun & 0 & 1 & 0 & 0 & 11,1 & 0 \\
f. 15 tahun & & & & & & \\
\hline 2. Jenis kelamin & 7 & 2 & 7 & 77,8 & 22,2 & 77,8 \\
a. Laki-laki & 2 & 7 & 2 & 22,2 & 77,8 & 22,2 \\
b. Perempuan & & & & & & \\
\hline 3. Agama & 9 & 9 & 8 & 100 & 100 & 88,9 \\
a. Islam & 0 & 0 & 1 & 0 & 0 & 11,1 \\
b. Katolik & & & & & & \\
\hline 4. Pendidikan & 3 & 4 & 4 & 33,3 & 44,4 & 44,4 \\
a. Pendidikan rendah & 6 & 5 & 5 & 66,7 & 55,6 & 55,6 \\
b. Pendidikan tinggi & & & & & & \\
\hline 5. Pekerjaan & 3 & 2 & 3 & 33,3 & 22,2 & 33,3 \\
a. Tidak bekerja & 6 & 7 & 6 & 66,7 & 77,8 & 66,7 \\
b. Bekerja & & & & & & 100 \\
\hline 6. Hubungan anak & 9 & 9 & 100 & 100 & \\
a. Orang tua kandung & 9 & 9 & & & \\
\hline
\end{tabular}




\begin{tabular}{lllllll}
\hline 7. Waktu merawat & & & & & & \\
a. $<4$ ja & 2 & 2 & 3 & 22,2 & 22,2 & 33,3 \\
b. 4-8 jam & 2 & 1 & 2 & 22,2 & 11,1 & 22,2 \\
c. $>8$ jam & 5 & 6 & 4 & 55,6 & 66,7 & 44,4 \\
\hline
\end{tabular}

Berdasarkan tabel 1 menjelaskan karakteristik responden berdasarkan usia didapatkan dari 9 responden (pada kelompok I) sebagian besar responden berusia 10 tahun dan 14 tahun yaitu masing - masing berjumlah $(33,3 \%)$. Pada kelompok II sebagian besar responden berusia 13 tahun sebanyak 3 orang $(33,3 \%)$ dan pada kelompok III sebagian besar responden berusia 10 tahun sebanyak 6 orang $(66,7 \%)$.

Karakteristik responden berdasarkan jenis kelamin didapatkan dari 9 responden (pada kelompok I dan kelompok III) sebagian besar responden adalah laki-laki sebanyak 7 orang $(77,8 \%)$ dan pada kelompok II sebagian besar responden adalah perempuan yaitu 7 orang $(77,8 \%)$. Karakteristik responden berdasarkan agama didapatkan dari 9 responden (pada kelompok I, II, dan III) sebagian besar responden adalah agama islam yaitu sebanyak 9 orang $(100 \%)$ dan 8 orang $(88,9 \%)$.

Karakteristik responden berdasarkan pendidikan orang tua didapatkan dari 9 responden (pada kelompok I, II, dan III) sebagian besar responden adalah pendidikan tinggi yaitu sebanyak 6 orang $(66,7 \%), 5$ orang $(55,6 \%)$. Untuk karakteristik responden berdasarkan pekerjaan orang tua didapatkan dari 9 responden (kelompok I, II, dan III) adalah bekerja sebanyak 6 orang $(66,7 \%)$, 7 orang $(77,8 \%)$ dan 6 orang $(66,7 \%)$.

Karakteristik hubungan dengan anak didapatkan dari 9 responden pada masingmasing kelompok semua responden adalah orang tua kandung yaitu sebanyak 9 responden $(100 \%)$. Karakteristik responden berdasarkan waktu merawat anak didapatkan dari 9 responden pada kelompok I, II dan III adalah $>8$ jam yaitu sebanyak 5 responden $(55,6 \%), 6$ responden $(66,7 \%)$, dan 4 responden $(44,4 \%)$.

\section{Kemampuan Merawat Diri Sebelum dan Sesudah Intervensi Video Interaktif, Media Gambar, Video Interaktif + Media Gambar}

Tabel. 2

Perbedaan Rata-Rata Kemampuan Merawat Diri Sebelum dan Sesudah Intervensi Video Interaktif, Media Gambar, Video Interaktif + Media Gambar

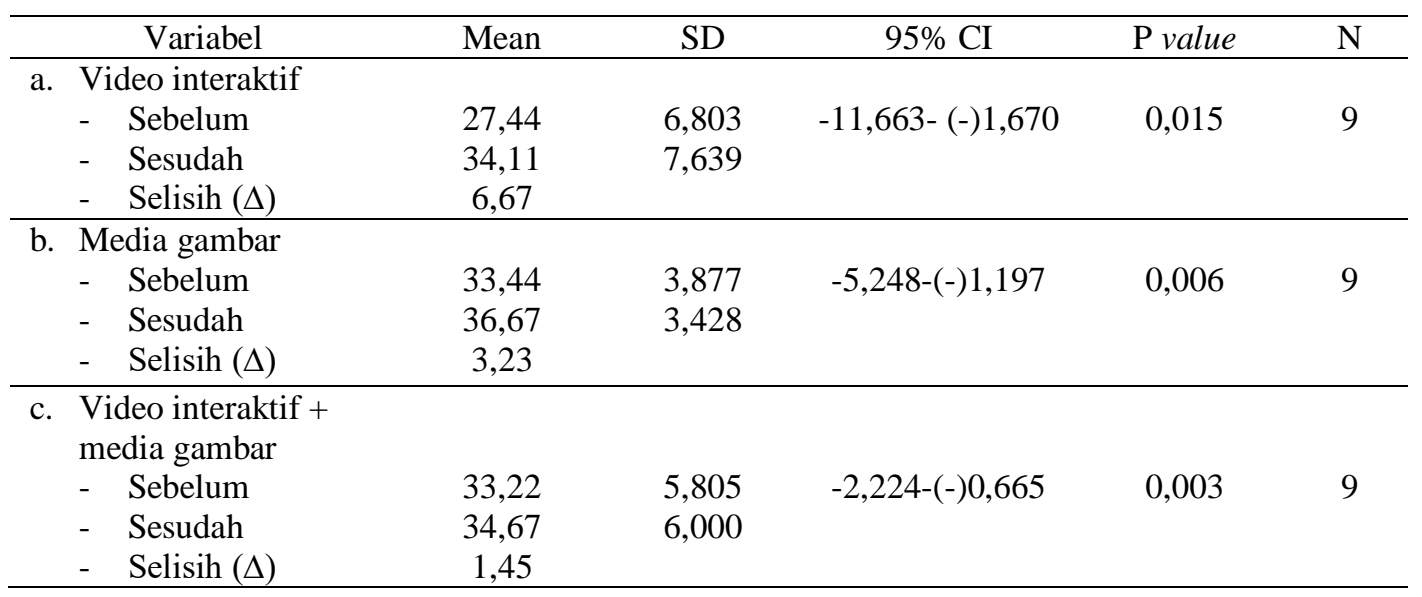


Berdasarkan tabel 2 menunjukkan bahwa pada kelompok anak yang diberikan intervensi video interaktif terjadi peningkatan kemampuan merawat diri. Nilai selisih antara sebelum dan sesudah diberikan intervensi adalah 6,67. Hasil uji statistik didapatkan nilai $\mathrm{p}=0,015$ dengan derajat kepercayaan 95\% (-11,663-(-)1,670), dapat disimpulkan ada perbedaan yang signifikan antara kemampuan merawat diripada anak tunagrahita sebelum dan sesudah diberikan intervensi video interaktif.

Tabel diatas juga menunjukkan bahwa pada kelompok intervensi media gambar terjadi peningkatan kemampuan merawat diri. Nilai selisih antara sebelum dan sesudah intervensi adalah 3,23. Hasil uji statistik didapatkan nilai $\mathrm{p}=0,006$ dengan derajat kepercayaan 95\% (-5,248-(-)1,197), dapat simpulkan bahwa ada perbedaan yang signifikan antara kemampuan merawat diripada anak tunagrahita sebelum dan sesudah dilakukan intervensi media gambar.

Berdasarkan tabel diatas menunjukkan bahwa pada kelompok intervensi video interaktif+media gambar terjadi peningkatan kemampuan merawat diri. Nilai selisih antara sebelum dan sesudah intervensi adalah 1,45. Hasil uji statistik didapatkan nilai $\mathrm{p}=0,003$ dengan derajat kepercayaan 95\% (-2,224-(-)0,665), dapat simpulkan bahwa ada perbedaan yang signifikan antara kemampuan merawat diripada anak tunagrahita sebelum dan sesudah dilakukan intervensi video interaktif+media gambar.

\section{PEMBAHASAN}

\section{Usia}

Rata-rata usia anak dalam penelitian ini adalah berada pada rentang usia sekolah. Usia anak sekolah adalah anak yang berusia 6 tahun sampai 12 tahun (Hockenberry \& Wilson, 2009). Semua anak tersebut merupakan anak tunagrahita sedang. Pada anak tunagrahita sedang dengan usia sekolah mampu melakukan kegiatan sehari-hari termasuk merawat diri namun anak tersebut harus dilatih terlebih dahulu. Pada kondisi ini anak tunagrahita sedang berdasarkan tingkatan sistem keperawatan menurut Orem adalah berada pada sistem yang mengkompensasi sebagian (partially compensatory nursing system), dimana perawatan yang diberikan adalah tidak sepenuhnya ini artinya perawat memiliki tugas dan tanggung jawab bagaimana agar anak dengan tunagrahita sedang ataupun keluarga mampu mandiri dalam pemenuhan kebutuhannya dalam perawatan diri, setelah dilakukan intervensi dengan menggunakan video interaktif dan gambar sebagai media pembelajaran di sekolah menunjukan hasil yang efektif terhadap peningkatan kemampuan anak dalam merawat diri.

\section{Jenis Kelamin}

Rata-rata jenis kelamin anak dalam penelitian ini adalah berjenis kelamin lakilaki. Anak tunagrahita lebih banyak terjadi pada anak laki-laki dari pada anak perempuan (Sandra, 2010). Keterbatasan tersebut tidak dapat dideteksi secara dini dari jenis kelamin apabila anak mengalami disabilitas atau tidak. Penelitian yang dilakukan oleh McDougall \& Miller (2009) didapatkan bahwa tidak terdapat hubungan yang signifikan antara anak laki-laki dan perempuan usia sekolah dalam keterbatasan melakukan aktivitas harian.

Kejadian tunagrahita secara signifikan lebih tinggi pada laki-laki dibandingkan perempuan degan ratio 1,4: 1 untuk tunagrahita berat dan 1,9: 1 untuk tunagrahita sedang. Lebih tingginya angka kejadian tersebut disebabkan karena kerusakan genetic pada kromosom $\mathrm{X}$ sehingga menyebabkan terjadinya mutasi pada kromosom $\mathrm{X}$ (Vasconcelos, 2004; Tzschach \& Ropers, 2007). 


\section{Pendidikan Orang Tua}

Pendidikan merupakan suatu usaha untuk mengembangkan kemampuan didalam dan diluar sekolah yang akan berlangsung seumur hidup (Wartonah, 2010). Pendidikan orang tua akan berkontribusi dalam meningkatkan kemampuan merawat diripada anak tunagrahita. Seseorang dengan pendidikan tinggi akan mampu mengelola, mengatasi dan menggunakan koping efektif dan konstruktif daripada seseorang yang memiliki pendidikan rendah (Saddock, 2010). Hal tersebut akan memberikan dampak positif terhadap kemampuan orang tua dalam merawat anak tunagrahita.

\section{Pekerjaan Orang Tua}

Sebagian besar orang tua yang merawat anak tunagrahita adalah bekerja. Walaupun bekerja, orang tua tetap memiliki waktu untuk memfasilitasi anak dengan mencari akses informasi misalnya melalui internet dan lain - lain terkait cara perawatan diri khususnya kepada anak tunagrahita. Hal tersebut terlihat pada ketiga kelompok intervensi, didapatkan peningkatan yang signifikan terhadap kemampuan merawat dirianak.

\section{Hubungan dengan Anak}

Semua anak tunagrahita dalam penelitian ini dirawat oleh orang tua kandung. Keterlibatan orang tua dalam merawat anaknya merupakan tugas dan tanggung jawab orang tua. Dengan dirawat orang tua kandung akan lebih terjalin kedekatan anatara orang tua dan anak secara psikologis. Meskipun pada beberapa keluarga yang merawat anak tunagrahita ada rasa malu akan stigma yang ada dimasyarakat.

\section{Waktu Merawat Anak}

Rata-rata waktu yang dimiliki oleh orang tua dalam merawat anaknya adalah $>8$ jam dalam sehari. Merawat anak tunagrahita akan menimbulkan suatu beban bagi keluarga. Menurut WHO (2008) beban keluarga ada dua jenis yaitu beban subyektif dan beban obyektif. Beban subyektif adalah beban yang berhubungan dengan reaksi psikologis anggota keluarga meliputi perasaan kehilangan, kesedihan, cemas dan malu dalam situasi sosial, koping stress terhadap gangguan perilaku dan frustasi yang disebabkan karena perubahan hubungan.

Beban objektif adalah beban yang berhubungan dengan masalah dan pengalaman anggota keluarga meliputi gangguan hubungan antara anggota keluarga, terbatasnya hubungan sosial dan aktifitas kerja, kesulitan finansial dan dampak negatif terhadap kesehatan fisik anggota keluarga. Selain hal tersebut, beban waktu merupakan salah satu faktor yang mempengaruhi perawatan anak tunagrahita. Penelitian yang dilakukan Napolion (2010) didapatkan bahwa beban waktu yang dirasakan oleh keluarga terjadi karena hampir seluruh waktu yang ada dihabiskan untuk mengasuh dan merawat anak yang mengalami tunagrahita.

\section{Pengaruh Video Interaktif, Media Gambar, Video Interaktif dan Media Gambar terhadap Kemampuan Merawat Diri Anak Tunagrahita}

Berdasarkan penelitian didapatkan hasil bahwa terdapat pengaruh yang signifikan pada pemberian intervensi penggunaan media pembelajaran dengan menggunakan video interaktif, gambar, video interaktif dan gambar terhadap kemampuan merawat diri pada anak tuna grahita sedang. Sistem keperawatan yang digunakan pada anak tunagrahita sedang yaitu perawatan yang diberikan adalah tidak sepenuhnya karena anak tuna 
grahita sedang mampu untuk dilatih dalam pemenuhan kebutuhan merawat diri. Melalui penggunaan media pembelajaran dengan menggunakan media video interaktif dan gambar dapat membantu anak dan orang tua dalam peningkatan kemampuan merawat diri, sehingga anak dapat mandiri melakukan perawatan diri seperti apa yang dilihat dan didengar dari media tersebut dan membantu meringankan beban orang tua dalam merawat anak tunagrahita sedang.

\section{Video Interaktif}

Rata-rata kemampuan merawat diri anak tunagrahita sebelum dan sesudah dilakukan intervensi video interaktif mengalami peningkatan dengan nilai selisih $(\Delta)=6,67$. Hasil uji paired $t$ test didapatkan bahwa ada pengaruh yang signifikan terhadap kemampuan merawat dirianak sebelum dan sesudah diberikan intervensi video interaktif ( $\mathrm{p}$ value $=0,015$ ). Peningkatan nilai kemampuanmerawat dirisetelah diberikan intervensi video interaktif lebih tinggi dibandingkan intervensi yang lainnya. Media video interaktif merupakan media yang mengandalkan indera pendengaran dan indera peglihatan sehingga mampu meningkatkan minat siswa dalam beajar karena penyampaian yang lebih menarik sehingga siswa menyimak sekaligus melihat gambar (Lambert et al., 2013).

Hal tersebut akan memudahkan anak untuk mengingat kembali proses pembelajaran yang mengandalkan indera pendengaran dan penglihatan sehingga anak akan melakukan kegiatan perawatan diri di rumah sesuai dengan apa yang di dengar dan di lihat melalui video interaktif tersebut. Penelitin yang dilakukan oleh Zhafirah (2014) didapatkan hasil bahwa ada perbedaan bermakna antara peningkatan pengetahuan sebelum dan sesudah diberikan edukasi terkait kesehatan oral dengan media video animasi dengan non animasi pada anak tungrahita ringan $(\mathrm{p}=0,000)$. Oleh karena itu, penggunaan media video interaktif akan lebih mudah dan menarik bagi anak tunagrahita sedang sehingga penggunaan video interaktif lebih cocok digunakan sebagai media edukasi kesehatan kepada anak tunagrahita sedang dan dapat di terapkan sebagai salah satu media pembelajaran di SKH Negeri 01 Serang Banten. Sarana dan prasarana yang kurang mendukung di sekolah tersebut dimana ketersediaan LCD yang kurang memadai yaitu hanya tersedia satu LCD sehingga penerapan pembelajaran menggunakan video interaktif tidak bisa dilakukan secara intensif.

\section{Media Gambar}

Rata-rata kemampuan merawat diri anak tunagrahita sebelum dan sesudah dilakukan intervensi media gambar mengalami peningkatan dengan nilai selisih $(\Delta)=3,23$. Hasil uji paired $t$ test didapatkan bahwa ada pengaruh yang signifikan kemampuan merawat dirianak sebelum dan sesudah diberikan intervensi media gambar ( $\mathrm{p}$ value $=0,006)$.

Terjadinya peningkatan kemampuan merawat diripada anak tunagrahita sedang sesudah diberikan intervensi media gambar meskipun peningkatannya kecil. Penggunaan media gambar pada anak tunagrahita sedang akan menimbulkan beban pada anak karena keterbatasan dalam kemampuan analisa pada anak, dimana anak harus mampu menginterpretasi apa yang dilihat sedangkan anak tunagrahita sedang hanya memiliki kemampuan untuk mampu latih. Melalui gambar tanpa adanya suara yang ditimbulkan sehingga anak akan mempunyai persepsi yang berbeda pada masingmasing gambar yang ditampilkan. Keterbatasan dengan nilai IQ 35-45 sehingga anak mampu dilatih namun anak tidak mengalami kemajuan dalam fungsi membaca ataupun 
memahami sesuatu yang lebih kompleks (Saddock, 2010; Hallan \& Kaufmann, 2006). Misalnya pada gambar menggosok gigi yang benar, karena pada gambar hanya memperlihatkan gambar seorang anak menggosok gigi tanpa adanya bagaimana cara berkumur-kumur yang benar, dan menyikat gigi dari dalam keluar, dan atas kebawah sehingga saat mengaplikasikan menggosok gigi yang benar anak hanya mengambil odol lalu menggosok gigi dibagian depan saja. Sehingga dalam kegiatan menggosok gigi pada media gambar sebagian anak masih dibantu oleh orang tuanya untuk membimbing anak.

Namun, media gambar ini lebih tepat digunakan pada anak tunagrahita ringan karena anak mampu didik dan mampu untuk menguasai keterampilan praktis serta membaca. Hal tersebut terlihat pada penelitian yang dilakukan oleh Suhaimi (2013) yang menyimpulkan bahwa ada peningkatan kemampuan membaca menggunakan gambar berseri untuk pada anak tunagrahita ringan. Penggunaan Media gambar pada pembelajaran anak tunagrahita sedang juga dapat dilakukan di SKH Negeri 01 Serang Banten mengingat didapatkan hasil yang cukup signifikan walaupun tidak seperti penggunaan video interaktif. Penggunaan Media gambar tidak membutuhkan biaya yang terlalu tinggi sehingga dapat mudah diterapkan di sekolah tersebut.

\section{Video Interaktif + Media Gambar}

Rata-rata kemampuan merawat diri anak tunagrahita sebelum dan sesudah dilakukan intervensi media video interaktif+media gambar mengalami peningkatan dengan nilai selisih $(\Delta)=1,45$. Hasil uji paired t test didapatkan bahwa ada pengaruh yang signifikan kemampuan merawat dirianak sebelum dan sesudah diberikan intervensi media gambar ( $\mathrm{p}$ value $=0,003$ ).

Nilai peningkatan kemampuan merawat diriyang cukup kecil pada penelitian ini disebabkan karena penggunaan 2 media yang berbeda pada saat yang bersamaan menimbulkan kebingungan pada anak sehingga anak tidak bisa fokus terhadap perawatan diri yang dilihatkan melalui media tersebut. Keterbatasan anak tunagrahita sedang dalam memahami sesuatu dan menganalisis yang telah diajarkan sehingga penggunaan 2 media saat bersamaan tidak direkomendasikan karena akan menimbulkan kebingungan sehingga anak akan jenuh dengan kegiatan pembelajaran.

\section{SIMPULAN}

Sebagian besar responden berusia usia sekolah, berjenis kelamin laki-laki, agama islam, pendidikan tinggi pada orang tua, orang bekerja, hubungan dengan anak adalah orang tua kandung, pengetahuan tinggi pada orang tua dan waktu luang dalam merawat anak adalah $>8$ jam

Terjadi peningkatan rata-rata skor kemampuan merawat diri pada anak tunagrahita sebelum dan sesudah diberikan intervensi video interaktif. Terjadi peningkatan rata-rata skor kemampuan merawat diri pada anak tunagrahita sebelum dan sesudah diberikan intervensi media gambar.

Terjadi peningkatan rata-rata skor kemampuan merawat diri pada anak tunagrahita sebelum dan sesudah diberikan intervensi video interaktif+media gambar. Terdapat perbedaan yang signifikan setelah dilakukan ketiga intervensi namun yang lebih berpengaruh adalah penggunaan video interaktif dalam meningkatkan kemampuan merawat diri pada anak tunagrahita. 


\section{SARAN}

\section{Bagi Pihak Sekolah}

Penggunaan media pembelajaran video interaktif dapat direkomendasikan sebagai media dalam proses pembelajaran yang efektif untuk meningkatkan kemampuan merawat diri pada anak tunagrahita sedang. Namun, media gambarpun lebih cocok digunakan pada anak tunagrahita ringan agar mendapatkan hasil yang lebih efektif.

\section{Bagi Peneliti Selanjutnya}

Peneliti menyarankan untuk mengembangkan isi video yang lebih interaktif khususnya video terkait perawatan diri pada anak tunagrahita sedang. Penelitian lebih lanjut tentang penggunaan media lainnya untuk meningkatkan kemampuan perawatan diri anak tunagrahita seperti media yang berbasis game atau media pembelajaran lainnya. Selain itu, penelitian selanjutnya dapat mengembangkan secara kualitatif pengaruh pengetahuan dan waktu merawat anak terhadap peningkatan kemampuan merawat diri anak tunagrahita sedang.

\section{Pendidikan Keperawatan}

Hasil penelitian ini dapat digunakan sebagai evidance based practice dan dimasukkan kedalam sub pokok bahasan materi tentang media pembelajaran pada anak tunagrahita.

\section{Bagi Orang Tua}

Peneliti menyarankan kepada orang tua untuk lebih aktif melatih anak dalam perawatan diri dan mengevaluasi kepada anaknya apa yang sudah di ajarkan di sekolah khususnya pembelajaran terkait dalam peningkatan kemampuan merawat diri.

\section{DAFTAR PUSTAKA}

Alligood, M. (2014). Nursing Theorist and Their Work ( $\left.8^{\text {th }} e d\right)$. St. Louis: Mosby Elsevier

Ayu, R. (2017). Efektivitas Media Huruf Bergambar terhadap Kemampuan Menulis Permulaan Bagi Siswa Tunagrahita Ringan. Jurnal Unublitar, 2(4), 48-56

Cahyo, A. (2011). Latihan Otak dan Daya Ingat dengan Menggunakan Ragam Media Audio Visual. Yogyakarta: Diva Press

Fajarwati, N., \& Sujarwanto, S. (2015). Media Pembelajaran Video Interaktif terhadap Peningkatan Keterampilan Membaca Permulaan Siswa Tunagrahita Ringan. Jurnal Unes, 7(2)

Hallan, D. P., \& kauffman, J. M. (2006). Exceptional LEARNERS: An Introduction to Special Education (10th ed). Boston: Pearson

Hermawan, C. (2013). Perilaku Adaptif Anak Tunagrahita di Sekolah Dasar Inklusif di SD Inklusf Hikmah Teladan Kota Cimahi. UPI

Hockenberry, J. M., \& Wilson, D. (2009). Wong: Essentials of Pediatric Nursing 8 ed. Philadelphia: Mosby Elsevier

Kemenkes RI. (2012). Riset Kesehatan Dasar. Jakarta: Depkes RI

Lambert, N. M., Fincham, F. D., Stillman, T. F., Lukas, R. D. (2009). More Gratitude, Less Materialism: The Mediating Role of Life Satisfaction. The Journal of Positive Psychology: Dedicated to Furthering Research and Promoting Good Practice, 4(1), 32-42 
McDougall, J., \& Miller, L. (2009). Measuring Chronic Health Condition and Disability as Distinct Concepts in National Surveys of School Aged Children in CANADA: a Comprehensive Review with Recommendations Based on the ICD-10 and ICF. Disability and Rehabilitation, 26(1), 922-939

Napolion, K. (2010). Pengalaman Keluarga dalam Merawat Anak Tunagrahita di Kelurahan Balumbang Jaya Kecamatan Bogor Barat Kota Bogor: Studi Fenomenologi. Universitas Indonesia

Saddock, B. J. (2010). Sinopsis psikiatri Jilid 2. Jakarta: Binarupa

Sandra, M. (2010). Anak Cacat Bukan Kiamat: Metode Pembelajaran dan Terapi untuk Anak Berkebutuhan Khusus. Yogyakarta: Kahati

Somantri, S. (2007). Psikologi Anak Luar Biasa. Bandung: PT. Refika Aditama

Suhaimi, S. (2013). Meningkatkan Kemampuan Membaca Pemahaman Melalui Gambar Berseri BAGI Anak Tunagrahita Ringan Kelas D III YAPEM Tarusan Pesisir Selatan. Jurnal ilmiah pendidikan khusus, 1(1)

Tzschach, A., \& Roper, H. (2007). Genetics of Mental Retardation. Dtsch Arztebl 2007; 104(20)

Vasconcelos, M. (2004). Mental Retardation. Journal de pediatria, 80(2), 571-582

Wartonah, T. (2010). Kebutuhan Dasar Manusia dan Proses Keperawatan. Jakarta: Salemba Medika

WHO. (2008). Special Needs Children. Diakses dari http://www/who.int/mediacentre/ Yayasan Pendidikan Dwituna Rawina. (2017). Diakses dari http://www.rawinala.org

Yayasan Pendidikan Dwituna Rawinala. (2008). Lentera: Light of the Hearth (vol 1, issue 1). Jakarta: Yayasan Pendidikan Dwituna Rawinala

Zhafirah, F., Bahar, A., \& Darwita, R. (2014). Perbedaan Peningkatan Pengetahuan Kesehatan Oral Menggunakan Video Animasi dengan Non Animasi pada Anak Tunagrahita Ringan (Studi Eksperimental di SLDB Ar Rahman Jakarta dan SDLB Mahardika Depok pada Agustus-Oktober 2014). Universitas Indonesia 